\title{
Principal's Preparation Program: Managing The Learning Environment Using ELCC Standards
}

J. Eric Tubbs, Kennesaw State University, USA

Michael S. Heard, Kennesaw State University, USA

Adrian Epps, Kennesaw State University, USA

\begin{abstract}
School principals need to be well prepared to manage school facilities assigned to their care. Educational leadership programs can make best use of the Educational Leadership Constituent Council (ELCC) Standards to develop a course of study to address school facility management issues. Every standard has its facility implications that lead to designing course activities to prepare school principals to be facility managers. A school facility management course can be effectively delivered by meeting all ELCC Standards.
\end{abstract}

Keywords: Learning Environment; ELCC Standards and Facilities; Managing The Learning Environment; and Student Performance and The Instructional Unit

\section{INTRODUCTION}

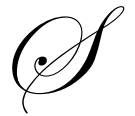

chool facility management is an important aspect of the daily operation of a school. School principals have major responsibilities over the safety, healthfulness, and efficient management of the school buildings under their administration (Chan \& McCleod, 2005; Berry, 2002; Dunklee \& Siberman 1991; Glatthorn, 2000; Shideler, 2001). Yet, many school principals are not prepared to address school facility issues (Chan \& Ledbetter, 1999; Bradley \& Protheroe, 2003; Brent \& Cianca, 2001; Futral, 1993; Shafer, 1999). Many of them actually learn about facilities on the job by trial and error. Some of them may simply assign facility responsibilities to their assistant principals or school custodians who periodically report to them about facilities. The problem with the first case is that principals learn through making mistakes. Sometimes mistakes can be very costly. In the second case, when principals leave the facility responsibilities to their employees they trust, they give up the opportunity of gaining first-hand experience in handling facility problems and are always at the mercy of their employees. Both cases are unhealthy for the long-term development of principalship. Principals need to be well prepared to address facility issues of the school buildings to which they are assigned. To meet this significant facility need of principalship, principal preparation programs have major responsibilities in developing their curricula to ensure that candidates have the knowledge, skills, and disposition to independently handle school facility problems.

\section{ELCC STANDARDS: THE FACILITY IMPLICATIONS}

Most principal preparation programs at the universities employ the Educational Leadership Constituent Council (ELCC) Standards (National Policy Board for Educational Administration, 2002) as guidelines to develop their programs and courses (Tubbs, 2008). The ELCC Standards consist of seven standards and each standard has its school facility implications.

\section{Standard 1}

Candidates who complete the program are educational leaders who have the knowledge and ability to promote the success of all students by facilitating the development, articulation, implementation, and stewardship of 
a school or district vision of learning supported by the school community. (National Policy Board for Educational Administration, 2002)

School facility implications - Principals need to have professional vision and firsthand knowledge of facility development of their school buildings and have included facility planning and maintenance as a component of the mission statements of their school improvement plans.

\section{Standard 2}

Candidates who complete the program are educational leaders who have the knowledge and ability to promote the success of all students by promoting a positive school culture, providing an effective instructional program, applying best practice to student learning, and designing comprehensive professional growth plans for staff (National Policy Board for Educational Administration, 2002).

School facility implications - Principals need to understand the conceptual background of how school facility impacts student and faculty performance, and thus create the conducive environment for better teaching and learning. School staff that has the facility responsibilities needs to be included in the staff professional development programs.

\section{Standard 3}

Candidates who complete the program are educational leaders who have the knowledge and ability to promote the success of all students by managing the organization, operations, and resources in a way that promotes a safe, efficient, and effective learning environment (National Policy Board for Educational Administration, 2002).

School facility implications: Principals need to be aware of all the building codes, environmental codes, and fire safety codes to ensure safe and healthy environments for teaching and learning. Principals must be able to anticipate potential safety issues that need to be addressed before reacting to problems already spiraling out of control. Principals need to learn how a management team can help manage school facilities more efficiently (Bessette, Bowen, \& Chan, 2006).

\section{Standard 4}

Candidates who complete the program are educational leaders who have the knowledge and ability to promote the success of all students by collaborating with families and other community members, responding to diverse community interests and needs, and mobilizing community resources (National Policy Board for Educational Administration, 2002).

School facility implications - Principals need to work with communities to share the use of school facilities and to involve the communities in planning and support of school facility improvement projects. They also need to be familiar with facility requirements to serve a diverse population.

\section{Standard 5}

Candidates who complete the program are educational leaders who have the knowledge and ability to promote the success of all students by acting with integrity, fairly, and in an ethical manner (National Policy Board for Educational Administration, 2002).

School facility implications - Principals need to employ their professional ethics to ensure fairness in the assignment of spaces and the distribution of equipment to all academic programs including the special education needs. 


\section{Standard 6}

Candidates who complete the program are educational leaders who have the knowledge and ability to promote the success of all students by understanding, responding to, and influencing the larger political, social, economic, legal, and cultural context (National Policy Board for Educational Administration, 2002).

School facility implications - Principals need to be fully aware of the political, social, and legal issues in relation to school facilities and to ensure that their schools stay in the forefront to reflect the significance of these issues.

\section{Standard 7}

Internship - The internship provides significant opportunities for candidates to synthesize and apply the knowledge and practice and develop the skills identified in Standards 1-6 through substantial, sustained, standardsbased work in real settings, planned and guided cooperatively by the institution and school district personnel for graduate credit (National Policy Board for Educational Administration, 2002).

School facility implications - Program candidates need to be fully involved with real school facility issues of today. Candidates will participate in hands-on facility planning and managing activities to resolve school facility problems.

\section{RATIONALE FOR STANDARDS}

\section{Implications}

As indicated in the above section, each of the ELCC Standards has implications for school facilities. In fact, each standard relates to school facilities to include what principals need to know. The standards serve as unique guidelines to prepare principals to be school facility managers. The following tasks can be performed to reflect the rationale of the ELCC Standards:

\section{Reflecting the Rationale of Standard 1}

Educational leadership programs need to be designed to broaden the candidates' horizon of educational facilities by introducing the significance of school facilities in the education process. Candidates need to be prepared to conduct student enrollment forecasting and school facility inventory as part of the school improvement plan. Candidates should possess the skills to perform assessment and projection of educational facilities. Leadership preparation in this area relates to knowledge, skills, and disposition that can well fit in a leadership introductory course or a school business management course (see Table 1).

\section{Reflecting the Rationale of Standard 2}

Program candidates should be introduced to school facility journals, school facility websites, and the Educational Resource Information Center Educational Facility Clearinghouse so that they can conduct a search on literature relating to the environmental factors that contribute to teaching and learning success. Recognition of custodial staff and familiarization with their recruitment, assignment, supervision, evaluation, and professional development process should be included in the leadership curriculum. Preparatory work in this area is mostly facility knowledge and skills that can be taught in a curriculum and instruction course, and a school business management course.

\section{Reflecting the Rationale of Standard 3}

Program candidates should be introduced to ways to access the latest version of building codes, fire safety codes, handicapped codes, and health requirements that dictate the daily operation of school buildings. They should be able to create aesthetically functional environments to support teaching and learning activities by meeting all the 
codes. The programs should introduce various emergency plans and communication systems to be tested in the candidates' schools. Candidates should be taught how a management team could be organized and implemented to improve school facility management. Facility knowledge and skills identified in this section can be taught mostly in a school business management course.

\section{Reflecting the Rationale of Standard 4}

Candidates need to be prepared to recognize community involvement in support of school facilities by cultivating good public relations. They need to be familiar with the school facility planning process to keep the public informed of new facility development and status of construction process. The programs should prepare candidates to invite community representatives to serve on facility planning committees and to work on collaborative use of school facilities. Principals need to be aware of the levels of community involvement in facility planning. To respond to the needs of diverse population, principals need to be familiar with the facility accommodation of the school. Facility knowledge and skills in this section can be incorporated in a school public relations course and a school business management course.

\section{Reflecting the Rationale of Standard 5}

Leadership programs need to prepare candidates to be ethical facility leaders by brainstorming them with fairness and integrity in the distribution of physical resources across programs such as space assignments, locations, equipment and other resource support. The following questions can be very challenging to the candidates: When the school is running out of space, what program needs to be moved to portable classrooms? Who should be given priority in the use of computer technology in their programs? This section of disposition preparation can be embedded in an educational ethics course and a school business management course.

\section{Reflecting the Rationale of Standard 6}

Leadership programs should prepare candidates to be aware of the latest political, social, and legal issues that relate to school facility development and to reflect upon their significance to the school board to make wise decisions. Plenty of examples should be provided to get the candidates acquainted with the type of issues they need to be aware of. Newspapers, professional journals, television, radio, and telecommunication should be widely used to track current political, social, and legal happenings for this purpose. Assignments should be given to candidates to present issues they noted for class discussion. Facility knowledge and skills in this section can be taught in a school law course, a social foundation course, and a school business management course.

\section{Reflecting the Rationale of Standard 7}

Leadership programs should prepare candidates to understand the different aspects of principals' involvement in school facilities: managing existing facilities and planning for new construction and renovation projects. Every principal has to manage his or her school building. Opportunities may come to involve principals in new facility and renovation project planning. Since safe and healthy environment is the prime concern of school administrators, candidates should be assigned to work on daily routine upkeep of facilities. They should be all exposed to working with assistant principals to supervise facilities and also with custodians who actually work on facilities. Candidates should also be arranged to participate in gaining experience in planning new and renovation projects should opportunity arises. Knowledge, skills, and disposition in this area can best be taught in Practicum and Portfolio classes.

\section{IMPLEMENTING THE ELCC STANDARDS AND KSDS}

\section{Standards and KSDs}

The goal of the ELCC Standards is to provide guidelines to educational leadership program coordinators to develop programs to enhance candidates' knowledge, skills, and dispositions (KSDs') in educational leadership. An examination of all six standards indicates a close relevance of candidates' knowledge and skills requirements and 
educational facilities. Principals' dispositions in planning and managing school facilities are embedded in Standard 1 (School Vision) and Standard 5 (Educational Ethics). When knowledge is placed at the basic level of principals' facility preparation, disposition is indisputably considered an element at the highest level. A school principal has to be prepared not only to possess knowledge and skills to plan and manage school facilities, but also has to have the disposition to examine the entire picture of facility impacts and needs (see Table 1). Focusing on KSDs' in facility preparation of school principals is in full support of the ELCC Standards.

Table 1: School Facility Management: Knowledge, Skills, and Dispositions (KSDs')

\begin{tabular}{|c|c|c|c|}
\hline Standard & Knowledge & Skills & Dispositions \\
\hline 1. School Vision & $\mathrm{X}$ & $\mathrm{X}$ & $\mathrm{X}$ \\
\hline 2. Instructional Leadership; Professional Development & $\mathrm{X}$ & $\mathrm{X}$ & \\
\hline 3. Use of Resources; Safe and Healthy Environment & $\mathrm{X}$ & $\mathrm{X}$ & \\
\hline 4. School Community Relationship; Diversity Issues & $\mathrm{X}$ & $\mathrm{X}$ & \\
\hline 5. Educational Ethics & $\mathrm{X}$ & $\mathrm{X}$ & \\
\hline 6. Political, Social, Legal, Economic, and Cultural Context & $\mathrm{X}$ & $\mathrm{X}$ & \\
\hline 7. Internship & $\mathrm{X}$ & $\mathrm{X}$ & $\mathrm{X}$ \\
\hline
\end{tabular}

\section{STRATEGIES TO PREPARE PRINCIPALS FOR FACILITY MANAGEMENT}

In preparing principals for school facility management, some working strategies can be identified to supplement the ELCC Standards in providing guidance to the development of educational leadership programs. The authors have direct experience in employing these strategies in leadership programs that proved to work.

\section{Field Experiences}

Involving program candidates in school facility planning experiences as part of their practicum has proved to be most beneficial to their understanding of the process in the real world. Visitation to school construction sites can be a very meaningful experience to them. Other activities could include visitation to professional facility planners to see exactly how systematic the process of planning and building schools has evolved.

\section{Professional Guest Speakers}

Guest speakers who have direct involvement with school facility management can be invited to speak in class. These speakers could include central office school planning director, principals experienced in facility planning, school design architects, and school maintenance director. Their live stories and examples could contribute to enriching the learning experiences of the program candidates.

\section{Hand-on Activities}

Hand-on activities can help to teach certain facility planning skills that may be difficult to explain fully on paper. These hand-on activities may include projecting student enrollment, reading construction drawings and specifications, and using scale ruler, light meter, thermostat, and surveying equipment (Chan, 1998). Hand-on activities may also involve trying out new management techniques in schools.

\section{Case Studies}

Real cases of facility planning and construction can be presented in class for discussion. Difficult situations created in these cases provide good learning experiences for program candidates. They challenge the candidates by requiring them to explore the many options by which these situations can be handled. 


\section{Simulations}

Simulations of facility planning and construction activities can be very powerful class exercises for candidates to understand the roles and responsibilities of personnel involved in the planning and construction process. Planning to compile the educational specifications, holding public hearings to discuss facility needs, presenting school facility projects for school board approval, preparing to open bids for school construction, meeting with architects and contractors to resolve construction disputes are good examples of simulation practices (Holt, 2002).

\section{Professional Associations}

Program candidates should be made aware of the professional associations promoting educational facilities, such as the Association of School Business Officials International and the Council of Educational Facility Planners International. Candidates are encouraged to seek for membership in these professional associations, to present papers in their annual conventions, and to publish in their professional journals.

\section{Resources}

Major publications on educational facilities should be introduced to program candidates. ERIC Clearinghouse on Educational Facilities and other major university websites should be explored as significant sources of information. Abstracts of master theses and doctoral dissertations provide an overview of academic studies on educational facilities.

\section{CONCLUSION}

Every school principal needs to have knowledge, skills, and disposition of school facility planning to be an effective facility manager of his/her school. As a supervisor of school custodial staff, the principal cannot be ignorant of the functional operation of the school building. He or she cannot afford failing to address facility concerns expressed by the public. University educational leadership programs have responsibilities to prepare school principals, who could effectively manage school facility functions. By following the directions of the six ELCC Standards, leadership program designers can foster school facility planning and maintenance experiences into the educational leadership curriculum. Activities of a professional practicum course can be designed to reflect greater involvement in school facilities. For years, educational leadership programs have not given enough attention to facility preparation of school principals. It is time to align our programs to ELCC Standards to prepare principals who can make good sense in turning bare school buildings to conducive teaching and learning environments.

\section{AUTHOR INFORMATION}

J. Eric Tubbs, author, is Associate Professor of Educational Leadership in the Bagwell College of Education at Kennesaw State University. He is a former high school and middle school principal. He has leadership experience in state government, private industry and business. Dr. Tubbs received his B. S. degree from The University of Akron, M. A. from California State University, Los Angeles, Ed. S. from Converse College, and obtained his Ed. D. in Educational Leadership from The University of Sarasota Florida. Dr. Tubbs has additional specialized training in school improvement, executive coaching, the superintendence, quantitative research, and other areas of leadership. Dr. Tubbs also served as graduate field experience program coordinator for the Department of Educational Leadership.

Michael S. Heard, Ph.D., J.D. is Associate Dean for The University College, Kennesaw State University. Dr. Heard currently teaches research and curriculum and instruction to assist students transitioning from high school to college. Dr. Heard serves on the schools' comprehensive program review committee and the assessment of learning council.

Dr. Epps Adrian Epps received his doctorate in Educational Leadership from Clark-Atlanta University and B.A. degree in Chemistry and M.Ed. degree in Science Education from Emory University. He is Associate Dean for 
Kennesaw State University's College of Mathematics and Director for The A.T.O.M.S. Center. Her also teaches Educational leadership and is lead grant writer. Earlier in his career, he worked in the Office of Deputy Superintendent for Curriculum and Instruction, the Professional Development Department, Informational Services Division, and high school science teacher in APS.

\section{REFERENCES}

1. Berry, M. A. (2002). Healthy school environment and enhanced educational performance: The case of Charles Young Elementary School, Washington, DC. Retrieved April 9, 2005 from http://www.carpetrug.com/pdf_word docs/020112_Charles_Young.pdf

2. Bessette, H., Bowen, C., \& Chan, T. C. (2006). Effective teams for improved school facility management. School Business Affairs, 72(7), 6-9.

3. Bradley, W. S., \& Protheroe, N. (2003). The principal's role in school construction and renovation, Principal, 82(5), 38-41.

4. Brent, B., \& Cianca, M. (2001). Involving principals in school renovations: Benefit t or burden? Journal of Education Finance, 27, 729-740.

5. Chan, T. C. (1998, April). Bringing facility classes to the real world. A presentation to the Ninth International Conference on College Teaching and Learning at Jacksonville, FL.

6. Chan, T. C., \& Ledbetter, D. (1999). How to manage a new school building. Principal, 79(2), 25-26.

7. Chan, T. C., McCleod, D. (2005). The roles of principals in school Facility management. The Journal for the Liberal Arts and Sciences, 9(3), 28-33.

8. Dunklee, D. R., \& Siberman, R. M. (1991). Healthy buildings keep employees out of bed and employers out of court. School Business Affairs, 57(12), 19-22.

9. Futral, K. K. (1993). The principal's role in school renovation. Principal, 72(3), 30-33.

10. Glatthorn, A. A. (2000). The principal as curriculum leader. Thousand Oaks, CA: Corwin Press Inc.

11. Holt, C. R. (2002). School bond success: A strategy for building American schools. (2nd ed.). Lanham, MD: Scarecrow Press, Inc.

12. National Policy Board for Educational Administration (2002). Standards for advanced programs in educational leadership. Reston, VA: Author.

13. Shafer, P. (1999). Opening a new school: What else could go wrong? Principal, 79(2), 28-30.

14. Shideler, L. (2001). A clean school is a healthy school. American School and University, May, 52-56.

15. Tubbs, J. Eric (February, 2008). Best Practices of Educational Leadership Practicum Experiences in Georgia. Paper presented at the Association of Teacher Educators (ATE) Annual Conference on, Multiple Realities in Teacher Education: Sheraton New Orleans. 


\section{NOTES}

